\title{
The Role of Entrepreneurial Strategy, Network Ties, Human and Financial Capital in New Venture Performance
}

\author{
Najib Ullah Khan ${ }^{1}$, Shuangjie Li ${ }^{1}{ }^{1}$, Muhammad Nabeel Safdar ${ }^{2}$ and Zia Ullah Khan ${ }^{3}$ \\ 1 College of Economics and Management, Beijing University of Technology, Beijing 100124, China; \\ najibkhanbs18@yahoo.com \\ 2 School of Business, Zhengzhou University, Zhengzhou 450001, China; dr.nabeel.s@outlook.com \\ 3 Institute of Management Sciences, Peshawar 25000, Pakistan; ziaullah_com@yahoo.com \\ * Correspondence: lishuangjie2000@sohu.com
}

Received: 16 January 2019; Accepted: 4 March 2019; Published: 11 March 2019

\begin{abstract}
In the current era of globalization and competitive edge, the survival of newly established ventures has become a big challenge. Numerous studies have been carried out to discover factors that are essential for newly initiated ventures but the results are still fragmented. This study focuses on measuring the effect of entrepreneurial strategy, network ties, human capital and financial capital on new venture performance. A structured questionnaire was used to collect data from 196 registered firms located in the emerging market Pakistan. The results indicate that entrepreneurial strategy, network ties and financial capital have a significant positive effect, while human capital showed an insignificant effect on new venture performance. This research recommends owners and managers of new firms build effective entrepreneurial strategies, expand their networks with external bodies (other firms, government and financial institutions) to acquire useful resources that in turn can spur their performance. Further implications are discussed. Policy makers and responsible authorities are advised to encourage and support new ventures which in turn can contribute to GDP and economic development. Practical implications and suggestions are also discussed.
\end{abstract}

Keywords: financial capital; network ties; human capital; entrepreneurial strategy; new venture performance; South Asia; Pakistan

\section{Introduction}

In today's turbulent markets, the success of newly established ventures has become a key and challenging question. In response to this, numerous studies have been conducted in developing and developed countries. In other words, some of the studies have focused on the factors that may cause the failure of enterprises while others have discussed the success, growth, and performance (e.g., Ahlstrom 2010; Yang et al. 2018; Anwar et al. 2018a). However, the growth and success of newly established ventures are relatively low in emerging economies as compared to more developed, often Western ones. One area of research has discussed the failure of newly built ventures while others have focused on new venture success (e.g., Messersmith et al. 2018; Baidoun et al. 2018).

Major causes of the failure of new ventures include lack of resources, lack of support, lack of financial capital, environmental uncertainty and weak institutional support (Anwar 2018; Manev et al. 2005). In contrast, factors leading to the success of ventures include a strong relationship with external bodies, adequate resources, effective strategies and human resources (e.g., Adomako et al. 2018; Bruton et al. 2000; Milosevic 2018). Still a few shortcomings exist in previous studies as many of them have been conducted in developed economies while emerging economies were less often discussed. Moreover, the role of certain factors such as entrepreneurial strategy, network 
ties, human and financial capital in new venture success is rarely debated in emerging economies in South Asia, such as Pakistan.

Thus, this study examines the role of contemporary factors (e.g., entrepreneurial strategy, network ties, human and financial capital) in new venture success. Newly started firms face severe competition in dynamic markets. It is very difficult for them to enter into an unknown market. Hence, they require a unique entrepreneurial strategy and network ties to be successful in their mission. Strategy helps them to enter into the market while network support firms to create new customers, suppliers and business partners which can result in higher performance (Lechner and Gudmundsson 2014; Saha and Banerjee 2015).

Network ties are the characteristics of social capital. Network ties refer to the linkage and association of firms with customers, suppliers and business partners, etc. (Anwar et al. 2018b). At the early stage of a business startup, network activities play a significant role because entrepreneurs are afraid of failure but the network encourages them to proceed (Zhang and Li 2010). Human capital is comprised of the entrepreneur's knowledge, skills, experiences and background ability, etc., for the success of the firm. Particularly, the growth of new established firms is significantly influenced by human capital (Danso et al. 2016). Financial capital refers to finance, money, as well as financial resources, owned by a firm. For the startup of a new business, financial capital is a core driver because business at the initial stage face various unexpected shocks and finance can help them in theses case (Cooper et al. 1994).

Small and medium-sized enterprises (SMEs) in Pakistan significantly contribute to economic growth and GDP. The State Bank of Pakistan defines SMEs as "small enterprises are those which have employees up to 20 and annual sale up to Rs. 75 million. While medium enterprises in the services sector have employees from 21-250 and in manufacturing sectors the employees from 51-250 and annual sale for services and manufacturing enterprises from Rs.75 million to Rs.400 million". According to the World Bank Report (2009), there are 3.2 billion SMEs in Pakistan, which comprise of $95 \%$ of all businesses and contribute more than $40 \%$ to the country GDP. SMEDA (Small and Medium Enterprises Development Authority) established in October 1998 provides different policies and programs for the development and growth of SMEs. Hence, the survival of SMEs in such regions is important to alleviate poverty and to enhance economic growth.

The current study is an attempt to contribute to the existing literature of entrepreneurial strategy, network ties, human, financial capital and new venture success in several ways. For instance, as discussed earlier, previous studies have contributed much to the research of entrepreneurs' success and performance using different approaches and factors (e.g., Anwar et al. 2018a; Messersmith et al. 2018; Baidoun et al. 2018). However, few studies have examined the impact of entrepreneurial strategy, network ties, human, financial capital on new venture performance in emerging economies. There is a great need to explore the factors that can enhance the survival of SMEs in the long run and to protect them from failure in developing markets. In other words, SMEs in emerging economies contribute a significant portion to GDP and help in poverty alleviation (Degong et al. 2018). Still, many newly born ventures are unable to survive for the long run in emerging markets (e.g., Anwar and Shah 2018). Hence, this research facilitates SMEs to take a sustainable competitive position and enhance their growth in the dynamic market. Second, using the factors of entrepreneurial strategy, network ties, human and financial capital, this study contributes to the resource-based view (RBV) and social network theory. RBV theory claims that unique, rare and immutable tangible and intangible resources (e.g., human capital, network ties, strategies and financial capital) help firms to perform over other firms (Barney 1991). The social network theory indicates that strong ties with external bodies and partners enables ventures to gain valuable resources and spur growth (Burt et al. 2013). Furthermore, the failure of new ventures has become a challenge for SMEDA, policy makers and practitioners in emerging and developed economies. This research helps them modify their strategies for the growth and survival of newly initiated firms which in turn contribute to economic growth and development. 
This research is organized as follows: First, it discusses the background and importance of the study. In the proceeding section, the theoretical background, methodology and analysis are discussed. Finally, the discussion, contributions and conclusion are presented.

\section{Theoretical Background}

Existing theories about entrepreneurial orientation have limited evidence and information regarding the importance and contributions of entrepreneurial strategy, network ties and human, financial capital in the growth and success of new ventures. However, it is claimed that the combination of these factors; financial capital, social capital and human capital, are crucial and necessary for the success of new ventures (Mallon et al. 2015). In the initial stage, venture performance is significantly affected by several factors; particularly, human capital and financial capital are thought to play a significant role (Ahlstrom et al. 2018; Cooper et al. 1994). A new venture needs adequate resources and support to enhance its growth (Anwar et al. 2018b). RBV theory claims that a venture having enough tangible and intangible resources (human capital, network ties, strategies and financial capital) performs over other firms (Barney 1991). Resources can be acquired through social capital and network. A well-formed network and social capital strengthen the spirit of an entrepreneur to start a new business (Tata and Prasad 2015). The social network theory indicates that strong ties with external bodies and partners enables ventures to gain valuable resources and spur growth (Burt et al. 2013).

\section{Hypotheses Development}

\subsection{Entrepreneurial Strategy and New Venture Performance}

Strategy is a systematic plan of efforts to achieve long-term objectives (Cohen and Cyert 1973). From a business perspective, strategy is associated with different kinds of objectives. Enterprise strategy has been defined from different perspectives as per the study need and outcome. Table 1 provides a brief detail of the definitions of strategy used in previous studies.

Table 1. Enterprise Strategy Defection in Strategic Literatures.

\begin{tabular}{cll}
\hline Prospective & \multicolumn{1}{c}{ Author (Year) } & Enterprise Strategy Definition \\
\hline Society relationship & Schendel and Hofer (1979) & $\begin{array}{l}\text { A strategy which directly } \\
\text { discourses the relationship of an } \\
\text { organization with society. }\end{array}$ \\
\hline Mission and Vision & Freeman (1984) & $\begin{array}{l}\text { Consists of the answer to the } \\
\text { question “What do we stand for?" }\end{array}$ \\
Value creation & Steyn and Niemann (2008) & $\begin{array}{l}\text { It is a tool for combining societal } \\
\text { expectations, values, norms, and } \\
\text { standards into the firm's strategic } \\
\text { decision-making processes. }\end{array}$ \\
\hline Environmental issues & Stead and Stead (2000) & $\begin{array}{l}\text { Ethical foundation spirits beyond } \\
\text { the human community to } \\
\text { discourse environmental issues. }\end{array}$ \\
\hline Competitive Advantage & $\begin{array}{l}\text { Firm strategy to achieve } \\
\text { comparative advantage and } \\
\text { superior performance on the basis } \\
\text { of cost and uniqueness of product } \\
\text { in dynamic markets. }\end{array}$ \\
\hline
\end{tabular}

From a resource-based view perspective, strategy is defined as an "ongoing search for rent or above the normal rate of return. Rent is received through the effective utilization of an organization's capabilities and resources to gain competitive advantages" (Chandler and Hanks 1994). In the present study, we aim to use the strategy suggested by Porter (1980) who described a strategy as a firm's plan 
to achieve competitive advantage and superior performance. According to Porter (1980) competitive advantage and superior performance can be achieved through the cost leadership strategy and differentiation strategy which simply refers to competitive strategy. In a cost leadership strategy, a firm aims to provide products and services to their customer at the lowest price i.e., firms aim to be the lowest cost producer in the market and industry. In a differentiation strategy, firms aim to provide unique kinds of products and services to their customers i.e., the customers may perceive that the product is a new one (Porter 1980). Porter's competitive strategy is also known as the business strategy as well as enterprise strategy.

Both the cost leadership strategy and differentiation strategy (hereafter referred to as entrepreneurial strategy) were found to be significantly and positively related to new venture performance (Teeratansirikool et al. 2013). Especially in emerging economies such as Pakistan, entrepreneurial strategy plays a significant role in the competitiveness and success of newly established ventures (Anwar et al. 2018a). Similarly, some other studies also concluded that competitive strategy (entrepreneurial strategy) has a positive and significant impact on the firm's performance (Lechner and Gudmundsson 2014; Acquaah and Agyapong 2015; Sun et al. 2016). Therefore, we hypothesize:

Hypothesis 1 (H1). There is a significant positive relationship between entrepreneurial strategy and new venture performance.

\subsection{Network Ties and New Venture Performance}

Networks are defined as a group of actors (people, divisions or businesses) and their strategic links (community, family, finance \& business alliances, etc.) with each other (Johnsen and Johnsen 1999). Network is the concept of social capital and social capital is characterized by norms of recognized behaviors and trust, which permit participants to act effectively together in search of shared objectives (Flora 1998). Social capital is an important element which enables emerging entrepreneurs to establish networks with customers, suppliers, creditors, other businesses and institutions. Networks also identify opportunity and generate innovative and proactive ideas (Manev et al. 2005). Building relationships with government, other businesses and financial institutions is very important for newly started ventures in emerging economies such as Pakistan (Anwar et al. 2018b).

Both formal and informal network support are essential for enterprises to create the relationship with actors in their environment to gain essential resources, knowledge and support which cannot be accessed by them directly. Network ties, trust, and shared vision have been found to affect the performance of small firms by creating resources, providing knowledge and mounting new capabilities (Saha and Banerjee 2015). Firms try to establish different networks for different purposes. For example, marketing networks depend on the firm's management capacity and the firm's culture which results in a high business reputation. In general, all kinds of networks are carried out for the firm's growth and performance (Lechner and Dowling 2003).

The formal network with business association and industry association provides a variety of benefits such as managerial, financial and technical services as well as legal advice. Network ties bring a considerable improvement to a firm's performance (Saha and Banerjee 2015). Networking is a significant element in emerging economies for superior performance which is characterized by relational and collective culture (Manev et al. 2005). Based on the arguments concluded in previous studies, we propose the hypothesis:

Hypothesis 2 (H2). There is a significant positive relationship between network ties and new venture performance. 


\subsection{Human Capital and New Venture Performance}

Human capital theory describes human capital as the core driver to improve enterprise performance (Huang et al. 2016). Human capital uses various resources such as skills, knowledge, and abilities to improve the firm's performance, e.g., it has a strong relationship with the firm's profitability (Delaney and Huselid 1996; Samagaio and Rodrigues 2016). The importance of human capital increased recently because of its prominent role in newly started ventures (Felício et al. 2014). Entrepreneurial human capital is an essential element in tumbling the firm's insolvency fear in high technological firms, however results are not significant in low technological firms (Kato and Honjo 2015). It is also argued that human capital has a strong but weak relationship with entrepreneurs' success. Results also suggested that human capital dimensions have a different influence on venture success. A few dimensions are significant while others have an insignificant impact on entrepreneur success (Unger et al. 2011). Human capital matters much in the growth and development of newly initiated ventures as it is considered a critical driver of newly born firms (Capelleras et al. 2018).

Human capital results higher performance in young audit firms in competitive markets (Danso et al. 2016). Performance of new firms can be improved through a combination of complementary skills such as technical education, commercial experience as well as managerial technical skills (Ganotakis 2012). Human capital has become an intangible resource for the success of new venture performance. It has a positive influence on a firm's profitability and growth (Chen and Chang 2013; Doong et al. 2011). Therefore, we propose the hypothesis for human capital and firm performance:

Hypothesis 3 (H3). There is a significant positive relationship between human capital and new venture performance.

\subsection{Financial Capital and New Venture Performance}

Financial capital plays a significant role in the profitability of firms (Coleman 2007). Entrepreneurs with sufficient financial capital have low risk. Sufficient finance allows a firm to use resources effectively and to gain competitive advantage. However, newly established firms face a lot of financial troubles due to lack of internal finance. Particularly, initial capital (also referred to as internal funds) plays a significant role in business operations and sustainability (Huang 2016). In emerging markets such as Pakistan, adequate financial resources enable firms to expand and grow their business easily (Songling et al. 2018). In the initial stage of new ventures, financial capital is one of the most significant tool; it can generate a shield against accidental shocks and allows firms to pursue unique kinds of strategies that cannot be imitated by competitors (Cooper et al. 1994). In general, a firm's financial capital plays a crucial role in the operational and business cycle. Liabilities can be paid on time and new opportunities can be explored with sufficient funds. A new venture needs enough resources to improve performance as well as gain competitive advantages (Huang et al. 2012). Entrepreneurial finance has a significant influence on venture success (Huang 2016). Based on the available arguments, we propose the hypothesis:

Hypothesis 4 (H4). There is a significant positive relationship between financial capital and new venture performance.

The research model is presented in Figure 1. 


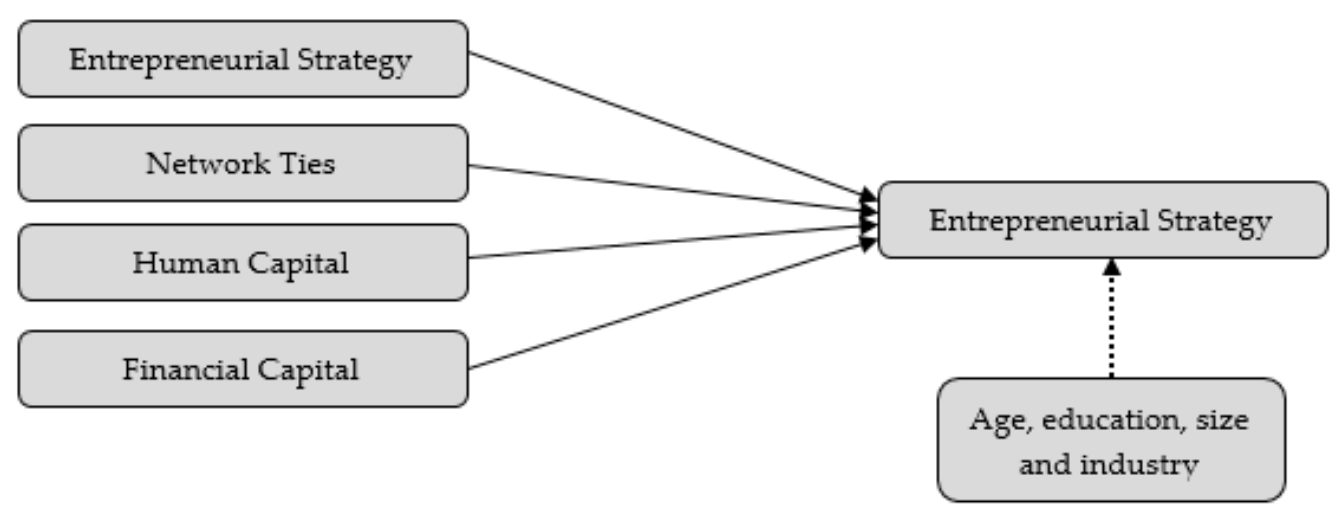

Figure 1. Research Model.

\section{Methodology}

\subsection{Sample and Data}

Data were collected from SMEs operating in Rawalpindi and Islamabad using a structured questionnaire. The registered SME list was taken from the Islamabad Chamber of Commerce and Industry (ICCI), which has approximately 4000 registered firms, and from the Rawalpindi Chamber of Commerce and Industry (RCCI), which has about 5408 registered firms. Therefore, the study population is approximately 9408 . These firms include manufacturing, services, and traders. However, we focused on newly established firms operated since the last 10 years.

\subsection{Procedure}

We distributed 250 questionnaires among the firms and asked them to be filled by the owners, executives and top managers because of their awareness about performance and strategies (Anwar et al. 2018c). SMEs are often reluctant to provide their information, so we ensured them about the information obtained through the questionnaire. We used a hard copy approach because an email survey gives a very low response rate and takes more time. We received 207 questionnaires back, of which 196 were only usable and the remaining were excluded from data analysis because they were not completely filled and some of them had missing information. The response rate achieved in this research was $67.6 \%$.

\subsection{Measurement of Variables}

\subsubsection{Dependent Variable}

The study uses the firms' performance as a dependent variable. Firms' performance can be measured via subjective and objective measures. The subjective measure uses self-reported data, collected through questionnaire and interview. Objective measure uses data collected from accounting records, financial statements, the stock exchange and the state bank. In the present study, we relied on the subjective measures of firms' performance because of several reasons.

1. Financial data of SMEs is not publicly available. Owners, executives, and top managers are not willing to provide accurate accounting data about their firms (Dibrell et al. 2014).

2. Previous studies suggested that there is a strong association between subjective end objective measures of firms' performance (Deligianni et al. 2016; Nandakumar et al. 2011).

3. Subjective measures cover broader dimensions of firms' performance as compared to objective measures (Dossi and Patelli 2010).

The firms' performance (financial performance and non-financial performance) was evaluated based on the previous study by Charoensukmongkol (2016), where owners and managers were asked 
"How well your firm performs relative to your major competitors based on the factors given below such return on assets, return on equity, market shares, return on investment, customer satisfaction and customer demand etc.".

\subsubsection{Independent Variables}

The study used four independent variables; entrepreneurial strategy, network ties, human capital and financial capital. Entrepreneurial strategy is measured with various dimensions and it is sometimes related to vision, mission, goal and objectives, planning and competitiveness. Different strategies were used in previous studies such as Wagner (2004), Chandler and Hanks (1994) and Zhu (2013) etc. In the present study, we relied on enterprise strategy related to the firm's competitiveness and comparative advantage. The strategy used for competitiveness, normally called cost leadership strategy and differentiation strategy, was used in previous study of Chandler and Hanks (1994).

The items used for financial capital, social capital and network ties were adopted from the previous study by Huang (2016) and were slightly modified as per the study's intended outcomes.

\subsubsection{Instrument/Scale Used}

All variables were measured using the 5 Likert scale. The independent variables were measured using the scale showing strongly disagree $=1$, disagree $=2$, neutral $=3$, agree $=4$, strongly disagree $=5$. However, the firm's performance was measured using the 5 Likert scale showing $1=$ extremely declined, $2=$ declined, $3=$ average, $4=$ improved, $5=$ extremely improved.

\subsubsection{Control Variables}

In order to reduce spurious results, we used the age of the firms, nature of industry and gender of owners, executives and top managers as control variables to check the impact of financial capital, network ties, social capital and enterprise strategy on venture performance. We controlled these variables as the previous studies concluded that these variables can impact firm performance. The firm's size, age, and nature of the industry were recommended to be controlled while checking outcomes of the firm's performance (Shirokova et al. 2013). The results indicated that age and size of the firms have a significant influence while educational background has insignificant influence on new venture performance.

\subsection{Demographic Profile of the Ventures}

Table 2 shows the demographic detail of the firms. In the descriptive statistics, the age of the firm, nature of industry and gender of the owners, managers and executives were shown with the total number and their percentage in the sample. It is clear that major firms in this study are manufacturing firms because they have a formal strategy process and plan when it comes to production and sales. A total of 188 respondents were male while only eight were female. It indicates that in Pakistan, females do not prefer to start a business because of an unsafe environment, culture, and barriers. Coleman (2007) suggested that women are less experienced, have low capital and often hold very small firms as compared to men. They also have limited financial knowledge and resources compared to established firms in dynamic markets. Size shows that 16 firms had 20-50 employees, 33 firms had 51-100 employees, 53 had 10-150 employees, 51 firms had 151-200 and 40 firms had 201-250 employees. The educational background of owners and managers showed that 70 owners and managers were intermediate and below, 44 had a Bachelor education, 74 had a Masters education and only eight owners and managers were $\mathrm{PhD}$ qualified. 
Table 2. Profile of Firms.

\begin{tabular}{|c|c|c|}
\hline Factors & Total Number & Percentage of Total \\
\hline \multicolumn{3}{|l|}{ Age of Firms } \\
\hline 1. 1 to 3 years & 75 & 38.3 \\
\hline 2. 4 to 7 years & 66 & 33.7 \\
\hline 3. 8 to 10 years & 55 & 28.1 \\
\hline \multicolumn{3}{|l|}{ Nature of Industry } \\
\hline 1. Manufacturing & 97 & 49.5 \\
\hline 2. Trading & 64 & 32.7 \\
\hline 3. Services & 35 & 17.9 \\
\hline \multicolumn{3}{|l|}{ Gender } \\
\hline 1. Male Owner, Executive, etc. & 188 & 95.9 \\
\hline 2. Female Owner, Executive, etc. & 8 & 4.1 \\
\hline \multicolumn{3}{|l|}{ Size of the firms } \\
\hline 1. 20-50 employees & 16 & 8.2 \\
\hline 2. $51-100$ & 33 & 16.8 \\
\hline 3. $101-150$ & 53 & 27.0 \\
\hline 4. $151-200$ & 54 & 27.6 \\
\hline 5. 201-250 & 40 & 20.41 \\
\hline \multicolumn{3}{|l|}{ Educational Background } \\
\hline 1. Intermediate and below & 70 & 35.7 \\
\hline 2. Bachelor & 44 & 22.4 \\
\hline 3. Master & 74 & 37.8 \\
\hline 4. $\mathrm{PhD}$, etc. & 8 & 4.1 \\
\hline Total & 196 & 100 \\
\hline
\end{tabular}

\section{Analysis and Results}

In this research, we executed several statistical tests such as reliability, descriptive statistics, normality, multicollinearity and correlation that are shown in Table 3. Hypotheses are tested through regression analysis given in Table 4.

\subsection{Reliability}

In the present study, Cronbach's alpha reliability was executed (see Table 3) to measure the internal consistency of the observed factors. Previous studies suggested that the reliability value above (0.60) is acceptable (e.g., Anwar et al. 2017). The reliability for financial capital is (0.70), network ties have reliability value (0.65), human capital reliability value shows $(0.62)$ and entrepreneurial strategy has value (0.80) while the highest value of firm performance found out (0.91). All the variables have reliability values within the accepted range which may be intended to provide trustable results.

Table 3. Correlation among Variables.

\begin{tabular}{|c|c|c|c|c|c|c|c|c|c|c|}
\hline Variables & Mean & S.D & 1 & 2 & 3 & 4 & 5 & 6 & 7 & 8 \\
\hline 1. Firm Age & - & - & 1 & & & & & & & \\
\hline 2. Size & - & - & -0.027 & 1 & & & & & & \\
\hline Education & - & - & 0.074 & $0.272 * *$ & 1 & & & & & \\
\hline Enterprise Strategy & 3.7474 & 0.72235 & 0.048 & $0.311^{* *}$ & $0.211^{* *}$ & $(0.80)$ & & & & \\
\hline 5. Network Capital & 3.1327 & 0.80956 & 0.111 & $0.380 * *$ & 0.115 & $0.378^{* *}$ & $(0.65)$ & & & \\
\hline 6. Human Capital & 3.2959 & 0.41505 & 0.032 & -0.020 & 0.020 & -0.031 & 0.095 & $(0.62)$ & & \\
\hline 7. Financial Capital & 3.0979 & 0.44876 & -0.036 & $0.155^{*}$ & $0.348^{* *}$ & $0.326^{* *}$ & 0.050 & -0.019 & $(0.76)$ & \\
\hline 8. Performance & 3.4852 & 0.51861 & 0.122 & 0.504 & 0.239 & 0.558 & 0.727 & 0.090 & 0.260 & $(0.91)$ \\
\hline Skewness & - & - & - & - & - & 0.376 & 0.340 & 0.501 & 0.648 & 0.354 \\
\hline Kurtosis & - & - & - & - & - & -1.153 & -1.512 & -0.907 & 0.045 & -1.488 \\
\hline VIF & - & - & - & - & - & 1.317 & 1.190 & 1.015 & 1.127 & 1.317 \\
\hline Tolerance & - & - & - & - & - & 0.759 & 0.840 & 0.986 & 0.888 & 0.759 \\
\hline
\end{tabular}

Note: $N=196,{ }^{*} p<0.05 . * * p<0.01$. 
Table 3 shows the mean and S.D of the study variables. The highest standard deviation is of the firm's age followed by network ties that show Standard Deviation (S.D) $=0.81,0.80$ respectively. It tells the highest variation as compared to other variables. The lowest variation in human capital shows $(S . D=0.42)$. The mean value of the study variables shows that all the factors have their mean value greater than 3 . The data are normally distributed as all the factors have their skewness and kurtosis values in the acceptable range \pm 2 (see Table 3) as recommended by George (2011). There is no multicollinearity issue in the data as all the factors have their Variance Inflation Factor (VIF) less than 3 and the tolerance values are greater than 0.10 that are shown in Table 3.

\subsection{Correlation}

Table 3 shows the Pearson's correlation results of two-tailed tests executed to forecast the nature of the relationships among variables. On the basis of correlation results, we cannot accept or reject the study hypotheses, however, it provides initial support for the hypotheses. There is a significant positive relationship between enterprise strategy and venture performance $(r=0.558, p<0.01)$. Network ties are significantly and positively related to venture performance $(r=0.727, p<0.01)$. The value $(r=0.090, p>0.01)$ shows that there is no significant relationship between social capital and venture performance. There is a significant positive relationship between venture performance and financial capital $(r=0.260, p \leq 0.01)$.

\subsection{Regression Analysis}

The model summary shows that the model is fit i.e., significant. It elaborates that all the independent variables of the study bring $66.7 \%$ change in new venture performance and the significance value shows (Sig. F change $=0.000$ ) that the model is significant. Multiple linear regression analysis was executed to test the hypotheses of the study (see Table 4). We used age, size of firms and educational background of owners and managers as control variables and entrepreneurial strategy, network ties, human and financial capital as independent variables, and venture performance as the dependent variable. Step 2 of Table 4 provides results for the main effect.

$\mathrm{H} 1$ of the study is supported as the resulted that entrepreneurial strategy has a significant positive impact on venture performance $(\beta=0.178, p<0.000)$. It can be interpreted that one unit increase in effectiveness of entrepreneurial strategy brings $17.80 \%$ increase in venture performance. Further, it can be elaborated that firms with good competitive strategy perform well.

Table 4. Hypotheses Testing (Regression).

\begin{tabular}{|c|c|c|c|c|c|c|c|c|}
\hline \multicolumn{9}{|c|}{ Coefficients } \\
\hline & \multirow[t]{2}{*}{ Model } & \multicolumn{2}{|c|}{$\begin{array}{l}\text { Unstandardized } \\
\text { Coefficients }\end{array}$} & \multirow{2}{*}{$\begin{array}{c}\begin{array}{c}\text { Standardized } \\
\text { Coefficients }\end{array} \\
\text { Beta }\end{array}$} & \multirow[t]{2}{*}{$t$} & \multirow[t]{2}{*}{ Sig. } & \multirow[t]{2}{*}{ Adj. $R^{2}$} & \multirow[t]{2}{*}{$\mathbf{R}^{2}$} \\
\hline & & B & Std. Error & & & & & \\
\hline \multirow{4}{*}{1} & (Constant) & 2.525 & 0.128 & & 19.725 & $* * *$ & $0.270 * * *$ & $0.282 * * *$ \\
\hline & Size & 0.207 & 0.027 & 0.481 & 7.556 & $* * *$ & & \\
\hline & Firm Age & 0.082 & 0.039 & 0.128 & 2.080 & $* *$ & & \\
\hline & Education & 0.054 & 0.035 & 0.098 & 1.540 & 0.125 & & \\
\hline \multirow{8}{*}{2} & (Constant) & 0.730 & 0.248 & & 2.945 & $* * *$ & $0.667^{* * *}$ & $0.678^{* * *}$ \\
\hline & Size & 0.086 & 0.020 & 0.201 & 4.267 & $* * *$ & & \\
\hline & Firm Age & 0.036 & 0.027 & 0.057 & 1.354 & 0.177 & & \\
\hline & Education & 0.014 & 0.025 & 0.025 & 0.539 & 0.591 & & \\
\hline & $\begin{array}{c}\text { Enterprise } \\
\text { Strategy }\end{array}$ & 0.178 & 0.035 & 0.249 & 5.168 & $* * *$ & & \\
\hline & Network Capital & 0.344 & 0.031 & 0.538 & 11.269 & $* * *$ & & \\
\hline & Human Capital & 0.063 & 0.052 & 0.051 & 1.214 & 0.226 & & \\
\hline & Financial Capital & 0.133 & 0.053 & 0.115 & 2.496 & $* * *$ & & \\
\hline
\end{tabular}

Note: ${ }^{* *}$ Significance at the $5 \%$ level; ${ }^{* * *}$ Significance at the $1 \%$ level. 
The values $(\beta=0.344, p<0.000)$ show that network ties have a significant positive impact on venture performance, which supported $\mathrm{H} 2$. One percent or unit increase in network ties can result in a $34.40 \%$ increase in venture performance. H3 is not supported as the values $(\beta=0.063, p>0.05)$ show that human capital has an insignificant impact on venture performance. However, the value is positive which describes that there is a positive but insignificant relationship between human capital and venture performance.

Financial capital has a significant positive impact on venture performance $(\beta=0133, p<0.000)$. These results support the study H4. Results show that one unit increase in financial capital brings a $13.23 \%$ increase in venture performance. Ventures with adequate financial capital perform well in markets. In the control variables, only the size of firms has a significance, while age and educational background do not play a significant role in the model.

Hypotheses remarks have shown in Table 5.

Table 5. Hypotheses Remarks.

\begin{tabular}{lcc}
\hline \multicolumn{1}{c}{ Hypotheses } & Remark \\
\hline H1. There is a significant positive relationship between entrepreneurial strategy and new venture performance. & Accepted \\
H2. There is a significant positive relationship between network ties and new venture performance. & Accepted & Rejected \\
H3. There is a significant positive relationship between human capital and new venture performance. & Accepted \\
H4. There is a significant positive relationship between financial capital and new venture performance. &
\end{tabular}

\subsection{Interview Results}

This study used a mixed approach (i.e., explanatory sequential) to explore useful insights. A mixed method approach increases the validity of results and provides a broader understanding of the phenomena (Jick 1979). Hence, we conducted a face-to-face interview with five members from top management including CEOs, HR and financial heads of newly started ventures. We asked six questions from CEOs, HR and financial heads to gain in-depth contributions.

1. Which of the following entrepreneurial strategies do you use to improve your performance?

- Cost leadership strategy

- Differentiation strategy

Answer: Three respondents (two CEOs and one financial manager) said that they focus on cost leadership strategy to enhance their profit. However, two respondents (HR managers) said that differentiation strategy plays a significant role in the improvement of profitability.

2. To acquire useful resources that can enhance your performance, do you build relationships with external bodies?

Answer: Four entrepreneurs (two CEOs, one HR manager and one financial manager) favored networking for acquiring valuable resources required for high performance and long term survival. However, one HR manager said that he has never tried to build networks for acquiring resources.

3. Does your human capital help in long term survival?

Answer: Two CEOs confirmed the importance of human capital in their venture success and profitability. Two HR managers also endorsed human capital in their firms as a crucial and intangible asset that is effective.

4. Have you enough financial capital to smoothly run your operation?

Answer: Three CEOs and two financial managers claimed that financial capital is the most significant factor in business success. 
5. Which of the following factor(s) you think is(are) more important for high profitability?

- Entrepreneurial Strategy

- Network Capital

- Human Capital

- Financial Capital

Answer: Based on the average responses of CEOs, financial and HR managers, the most important was network, followed by financial capital, entrepreneurial strategy and the least important was human capital for high performance.

6. What others factors do you think are most significant for long term survival?

Answer: Despite the above mentioned factors, we also let them disclose factors that can spur their survival. We received fragmented information as some enterprises claimed modern technology, new opportunities and new products while others were in favor of business expansion and massive number of customers.

Comparing the results of interview to questionnaires, a significant relationship exists between both as interview results endorse questionnaires.

\section{Discussion and Conclusions}

A plethora of research has been conducted to determine new venture success especially in emerging markets. However, the present study extends the existing literature by assessing the impact of financial capital, network ties, human capital and enterprise strategy on new venture performance. To achieve reliable results, we used a self-reported questionnaire.

In this study, we used the age of the firms, nature of business and gender of the executive, owners and top managers as control variables to check the impact of financial capital, network ties, human capital and entrepreneurial strategy on new venture performance in Pakistan. The regression analysis showed that all three control variables have insignificant influence on new venture performance. The results generated outcomes that age of firms, nature of industry and gender do not play a significant role in new venture performance.

However, the present study revealed that financial capital has a significant and positive relationship with new venture performance. The results supported our Hypothesis 1 proposed that financial capital and new venture performance have a significant and positive relationship. Similar results are also portrayed in previous studies. Consistent with Huang (2016), financial capital is a key factor, particularly for new ventures, because it helps firms to identify new opportunities and gain high performance in dynamic markets (Ahlstrom et al. 2018). In every stage of business operation, financial capital plays a significant role because firms can easily pay current liabilities, as well firms can utilize resources if sufficient funds are available. Our study favors Cooper et al. (1994) as financial capital is a crucial driver which protects firms from unexpected shocks.

Network ties were found to be significantly and positively related to new venture performance. The sample of the present study confirmed Hypothesis 2, that there is a significant and positive relationship between network ties and new venture performance. These results are in line with the previous studies such as Lechner and Lechner and Dowling (2003) who scrutinized that firms establish different kinds of networks for different purposes but the ultimate goal of all networking is to promote business and to gain superior performance. Also, Manev et al. (2005) pointed out that network ties have a significant influence on firm performance in emerging economies. Saha and Banerjee (2015) also concluded that networking is a significant element in firm performance. Manev et al. (2005) argued that networking is an important element for emerging entrepreneurs because it helps a firm establish a network with external partners which may help to identify new opportunities and increase performance. In general, network ties help firms to connect with a new market, supplier and new customers which may result in higher sales and profitability. 
Human capital was found to be positive but insignificant in the present study. The present study shows that human capital increases new venture performance but insignificantly. The present results do not support the Hypothesis 3 based on significance value. The results of the present study seem to be associated with previous studies such as Cooper et al. (1994) as some of the human capital is very strict and cannot be easily changed, and risk and benefit concerned with these factors can be expected. Similarly, meta-analysis results show that human capital dimensions have varied influence on venture success. All dimensions of intellectual capital do not significantly impact on entrepreneurs' success (Unger et al. 2011). Based on the study results we conclude that human capital is not a core driver in improving new venture performance in Pakistan. Other factors have greater importance and play a key role in the performance of a new venture. Krishna (2001) exposed that enterprises with social capital report poor performance.

Moving to the Hypothesis 4 that posited that there is a significant and positive relationship between entrepreneurial strategy and new venture performance is supported by the present study results. The same results found in previous studies such as Leitner and Güldenberg (2010) documented that the firms pursuing competitive strategy perform better than firms that have no competitive strategy. Firms pursuing such a strategy utilize modern technology, search for new ways of operation and thus result in higher performance in competitive markets. Lechner and Gudmundsson (2014) also concluded that the competitive strategy of an enterprise has a significant and positive impact on firm performance. Entrepreneurial strategy helps firms plan for the future market and opportunity. It helps to reduce different kinds of expenditures related to the operation, distribution, and marketing etc. and provide unique kinds of products so that customers purchase the product in bulk because they perceive that the product is new and offered at a lower price. Ultimately, sales increase resulting in a higher profit margin.

Correspondingly, the results indicate that the age of the firms, nature of industry and gender of the owner, executive and top managers do not play a significant role in the performance of new ventures. The most significant factors are the network ties that brings greater positive change in new venture performance as compared to financial capital and entrepreneurial strategy. However, entrepreneurial strategy has a greater influence on new venture performance as compared to financial capital and human capital. The study results also show that human capital has a positive but insignificant influence on new venture performance in the firms studied in Pakistan. It is a very important lesson for an entrepreneur, owner, executive, and top manager to give considerable attention to their network ties. They have to expand their network in order to bring greater positive change in the performance of newly established firms (Peng and Zhou 2005; Wang et al. 2008). However, owners, executives and top managers must also manage financial capital efficiently and create a strategy to enter into new markets as well as to grow and survive in dynamic markets.

\subsection{Implications for Practice}

Based on the present study results, we can say that financial capital, network ties, and entrepreneurial strategy are the significant and core factors followed by human capital in the success and performance of new venture creation and survival. Our findings showed that network ties are the most significant factor in the performance of a new venture that must be focused followed by entrepreneurial strategy, financial capital, and human capital. Firms with broader network ties connect with more suppliers, customers, and business partners which result in increased sales and improved performance. Particularly for new venture performance, network ties are the most significant element in the dynamic market. Similarly, entrepreneurial strategy also plays a significant role in the success of the new venture as well as financial capital. However, human capital is a less important factor as compared to other factors in the present study. So, owners, executives and top managers have to consider their network ties with external partners but not ignore entrepreneurial strategy, financial capital, and human capital. 


\subsection{Limitations and Future Research}

This study contributes to the existing literature by adding insights from Pakistan's emerging economy. The study also extends previous literature by examining key factors such as financial capital, network ties, human capital and entrepreneurial strategy which affect new venture performance in the emerging economy. However, the study is not free of limitations such as a small sample size, focused on a narrow area, only new ventures are targeted, as well as only core variables are selected as independent variables. The paper is very descriptive and the implied causality is questionable. If an emerging or pre-enterprise venture is assessed as promising, it can shape many of the explanatory variables. Similarly, the present study used few widely used statistic tests, i.e., correlation and regression, and it may be intended that some key outcomes can be generated by using other statistical tests. The study only focused on new ventures operating in the emerging economy of Pakistan.

In addition, as the study was conducted in the emerging economy of Pakistan, it would be more beneficial to conduct a study and compare developed and developing countries. The study used four independent variables (financial capital, network ties, human capital and entrepreneurial strategy) on new venture performance. Future researchers can use opportunity recognition as a mediator as well as entrepreneurial education as a moderator to gain more favorable outcomes. Similarly, the comparison between new venture performance and old venture performance can be conducted.

\subsection{Conclusions}

Ventures in the early stages face countless problems; lack of resources, lack of support and newness that hinder their growth and survival in the dynamic markets. In response to the external changes and smooth running of operational activities, they need adequate resources and support. Steered by RBV and the social network theory, this research examined the influence of entrepreneurial strategy, network ties, human capital and financial capital on the performance of newly established ventures. Hypotheses of the research were tested on a data set of 196 Pakistani firms. The results indicate that entrepreneurial strategy, network ties and financial capital significantly and positively contribute to new ventures performance while human capital does not play a significant role in the performance of new ventures. The results suggest that newly established ventures should focus initially on building effective entrepreneurial strategies, establish relationships with external ties and acquire adequate financial capital for their growth and performance. Policy makers and SMEDA are advised to encourage and support new ventures which in turn can contribute to GDP and economic development. Practical implications and suggestions are also discussed.

Author Contributions: N.U.K. has prepared the original draft of the paper. S.L. supervised the paper and academic writing. M.N.S. helped in data collection, entry and initial analysis, and Z.U.K. analyzed the data and helped in interpretation.

Funding: This research received no external funding.

Conflicts of Interest: The authors declare no conflict of interest.

\section{References}

Acquaah, Moses, and Ahmed Agyapong. 2015. The Relationship between competitive strategy and firm performance in Micro and Small Businesses in Ghana: The moderating role of managerial and marketing capabilities. Africa Journal of Management 1: 172-93. [CrossRef]

Adomako, Samuel, Albert Danso, Nathaniel Boso, and Bedman Narteh. 2018. Entrepreneurial alertness and new venture performance: facilitating roles of networking capability. International Small Business Journal 36: 453-72. [CrossRef]

Ahlstrom, David. 2010. Innovation and growth: How business contributes to society. Academy of Management Perspectives 24: 11-24. 
Ahlstrom, David, Douglas J. Cumming, and Silvio Vismara. 2018. New methods of entrepreneurial firm financing: Fintech, crowdfunding and corporate governance implications. Corporate Governance: An International Review 26: 310-13. [CrossRef]

Ahlstrom, David, Xiaohua Yang, Liang Wang, and Changqi Wu. 2018. A global perspective of entrepreneurship and innovation in China. Multinational Business Review 26: 302-18. [CrossRef]

Anwar, Muhammad. 2018. Business Model Innovation And SMEs Performance-Does Competitive Advantage Mediate? International Journal of Innovation Management 24: 1-37. [CrossRef]

Anwar, Muhammad, and Syed Zulfiqar Ali Shah. 2018. Managerial Networking and Business Model Innovation: Empirical Study of New Ventures in an Emerging Economy. Journal of Small Business E Entrepreneurship, 1-22. [CrossRef]

Anwar, Muhammad, Sher Zaman Khan, and Amin Ur Rehman. 2017. Financial Literacy, Behavioral Biases and Investor's Portfolio Diversification: Empirical Study of an Emerging Stock Market. Journal of Finance and Economics Research 2: 144-63. [CrossRef]

Anwar, Muhammad, Sher Zaman Khan, and Najib Ullah Khan. 2018a. Intellectual Capital, Entrepreneurial Strategy and New Ventures Performance: Mediating Role of Competitive Advantage. Business and Economic Review 10: 63-93. [CrossRef]

Anwar, Muhammad, Atiq Ur Rehman, and Syed Zulfiqar Ali Shah. 2018b. Networking and new venture's performance: Mediating role of competitive advantage. International Journal of Emerging Markets 13: 998-1025. [CrossRef]

Anwar, Muhammad, Syed Zulfiqar Ali Shah, and Sher Zaman Khan. 2018c. The role of personality in SMEs internationalization: empirical evidence. Review of International Business and Strategy 28: 258-82. [CrossRef]

Baidoun, Samir D., Robert N. Lussier, Maisa Burbar, and Sawsan Awashra. 2018. Prediction model of business success or failure for Palestinian small enterprises in the West Bank. Journal of Entrepreneurship in Emerging Economies 10: 60-80. [CrossRef]

Barney, Jay. 1991. Firm resources and sustained competitive advantage. Journal of Management 17: 99-120. [CrossRef]

Bruton, Garry D., David Ahlstrom, and Eunice S. Chan. 2000. Foreign firms in China: Facing human resources challenges in a transitional economy. SAM Advanced Management Journal 65: 4.

Burt, Ronald S., Martin Kilduff, and Stefano Tasselli. 2013. Social network analysis: Foundations and frontiers on advantage. Annual Review of Psychology 64: 527-47. [CrossRef] [PubMed]

Capelleras, Joan-Lluís, Ignacio Contin-Pilart, Martin Larraza-Kintana, and Victor Martin-Sanchez. 2018. Entrepreneurs' human capital and growth aspirations: The moderating role of regional entrepreneurial culture. Small Business Economics 52: 3-25. [CrossRef]

Chandler, Gaylen N., and Steven H. Hanks. 1994. Market attractiveness, resource-based capabilities, venture strategies, and venture performance. Journal of business venturing 9: 331-49. [CrossRef]

Charoensukmongkol, Peerayuth. 2016. The interconnections between bribery, political network, government supports, and their consequences on export performance of small and medium enterprises in Thailand. Journal of International Entrepreneurship 14: 259-76. [CrossRef]

Chen, Ming-Huei, and Yu-Yu Chang. 2013. The impacts of human capital in enhancing new venture's performance: Competence, motivation, and creativity. Journal of Knowledge-Based Innovation in China 5: 146-68. [CrossRef]

Cohen, Kalman J., and Richard M. Cyert. 1973. Strategy: Formulation, implementation, and monitoring. The Journal of Business 46: 349-67. [CrossRef]

Coleman, Susan. 2007. The role of human and financial capital in the profitability and growth of women-owned small firms. Journal of Small Business Management 45: 303-19. [CrossRef]

Cooper, Arnold C., F. Javier Gimeno-Gascon, and Carolyn Y. Woo. 1994. Initial human and financial capital as predictors of new venture performance. Journal of Business Venturing 9: 371-95. [CrossRef]

Danso, Albert, Samuel Adomako, John Ofori Damoah, and Moshfique Uddin. 2016. Risk-taking Propensity, Managerial Network Ties and Firm Performance in an Emerging Economy. Journal of Entrepreneurship 25: 155-83. [CrossRef]

Degong, Ma, Farid Ullah, Muhammad Khattak, and Muhammad Anwar. 2018. Do International Capabilities and Resources Configure Firm's Sustainable Competitive Performance? Research within Pakistani SMEs. Sustainability 10: 4298. [CrossRef]

Delaney, John T., and Mark A. Huselid. 1996. The impact of human resource management practices on perceptions of organizational performance. The Academy of Management Journal 39: 949-69. 
Deligianni, Ioanna, Pavlos Dimitratos, Andreas Petrou, and Yair Aharoni. 2016. Entrepreneurial orientation and international performance: The moderating effect of decision-making rationality. Journal of Small Business Management 54: 462-80. [CrossRef]

Dibrell, Clay, Justin B. Craig, and Donald O. Neubaum. 2014. Linking the formal strategic planning process, planning flexibility, and innovativeness to firm performance. Journal of Business Research 67: 2000-7. [CrossRef]

Doong, Shuh-Chyi, Hung-Gay Fung, and Jr-Ya Wu. 2011. Is social, financial, and human capital value enhancing? Evidence from Taiwanese firms. International Review of Economics $\mathcal{E}$ Finance 20: 395-405.

Dossi, Andre, and Lorenzo Patelli. 2010. You learn from what you measure: Financial and non-financial performance measures in multinational companies. Long Range Planning 43: 498-526. [CrossRef]

Felício, J. Augusto, Eduardo Couto, and Jorge Caiado. 2014. Human capital, social capital and organizational performance. Management Decision 52: 350-64. [CrossRef]

Flora, Jan L. 1998. Social capital and communities of place. Rural Sociology 63: 481-506. [CrossRef]

Freeman, R. Edward. 1984. Strategic Management: A Stakeholder Approach. Marshall: Pitman Publishing Inc.

Ganotakis, Panagiotis. 2012. Founders' human capital and the performance of UK new technology-based firms. Small Business Economics 39: 495-515. [CrossRef]

George, Darren. 2011. SPSS for Windows Step by Step: A Simple Study Guide and Reference, 17.0 Update, 10/e. Delhi: Pearson Education India.

Huang, Hao-Chen. 2016. Entrepreneurial resources and speed of entrepreneurial success in an emerging market: the moderating effect of entrepreneurship. International Entrepreneurship and Management Journal 12: 1-26. [CrossRef]

Huang, Hao-Chen, Mei-Chi Lai, and Kuo-Wei Lo. 2012. Do founders' own resources matter? The influences of business networks on start-up innovation and performance. Technovation 32: 316-27. [CrossRef]

Huang, Liang-Chih, David Ahlstrom, Amber Yun-Ping Lee, Shu-Yuan Chen, and Meng-Jung Hsieh. 2016. High performance work systems, employee well-being, and job involvement: An empirical study. Personnel Review 45: 296-314. [CrossRef]

Jick, Todd D. 1979. Mixing qualitative and quantitative methods: Triangulation in action. Administrative Science Quarterly 24: 602-11. [CrossRef]

Johnsen, Rhona E., and Thomas E. Johnsen. 1999. International market development through networks: The case of the Ayrshire knitwear sector. International Journal of Entrepreneurial Behavior and Research 5: 297-312. [CrossRef]

Kato, Masatoshi, and Yuji Honjo. 2015. Entrepreneurial human capital and the survival of new firms in high-and low-tech sectors. Journal of Evolutionary Economics 25: 925-57. [CrossRef]

Krishna, Anirudh. 2001. Moving from the stock of social capital to the flow of benefit: The role of agency. World Development 29: 925-943. [CrossRef]

Lechner, Christian, and Michael Dowling. 2003. Firm networks: external relationships as sources for the growth and competitiveness of entrepreneurial firms. Entrepreneurship E Regional Development 15: 1-26.

Lechner, Christian, and Sveinn Vidar Gudmundsson. 2014. Entrepreneurial orientation, firm strategy and small firm performance. International Small Business Journal 32: 36-60. [CrossRef]

Leitner, Karl-Heinz, and Stefan Güldenberg. 2010. Generic strategies and firm performance in SMEs: A longitudinal study of Austrian SMEs. Small Business Economics 35: 169-89. [CrossRef]

Mallon, Mark, Ryan Lee Klinger, and Stephen E. Lanivich. 2015. Configurations of human, social, and financial capital as predictors of new family firm success. In Academy of Management Proceedings. Briarcliff Manor: Academy of Management, p. 12778.

Manev, Ivan M., Bojidar S. Gyoshev, and Tatiana S. Manolova. 2005. The role of human and social capital and entrepreneurial orientation for small business performance in a transitional economy. International Journal of Entrepreneurship and Innovation Management 5: 298-318. [CrossRef]

Messersmith, Jake G., Pankaj C. Patel, and Christopher Crawford. 2018. Bang for the buck: Understanding employee benefit allocations and new venture survival. International Small Business Journal 36: 104-25. [CrossRef]

Milosevic, Miona. 2018. Skills or networks? Success and fundraising determinants in a low performing venture capital market. Research Policy 47: 49-60. [CrossRef] 
Nandakumar, M. K., Abby Ghobadian, and Nicholas O’Regan. 2011. Generic strategies and performance-evidence from manufacturing firms. International Journal of Productivity and Performance Management 60: 222-51. [CrossRef]

Peng, Mike W., and Jessie Qi Zhou. 2005. How network strategies and institutional transitions evolve in Asia. Asia Pacific Journal of Management 22: 321-36. [CrossRef]

Porter, Michael E. 1980. Competitive Strategy: Techniques for Analyzing Industry and Competitors. New York: Free Press.

Saha, Mausumi, and Sharmistha Banerjee. 2015. Impact of social capital on small firm performance in West Bengal. Journal of Entrepreneurship 24: 91-114. [CrossRef]

Samagaio, Antonio, and Ricardo Rodrigues. 2016. Human capital and performance in young audit firms. Journal of Business Research 69: 5354-59. [CrossRef]

Schendel, D., and C. W. Hofer. 1979. Strategic Management: A New View of Business Policy and Planning. Boston: Little, Brown, and Co.

Shirokova, Galina, Gina Vega, and Liubov Sokolova. 2013. Performance of Russian SMEs: Exploration, exploitation and strategic entrepreneurship. Critical Perspectives on International Business 9: 173-203. [CrossRef]

Songling, Yang, Muhammad Ishtiaq, Muhammad Anwar, and Hamid Ahmed. 2018. The role of government support in sustainable competitive position and firm performance. Sustainability 10: 3495. [CrossRef]

Stead, Jean Garner, and Edward Stead. 2000. Eco-enterprise strategy: standing for sustainability. Journal of Business Ethics 24: 313-29. [CrossRef]

Steyn, B., and L. Niemann. 2008. Institutionalising the strategic role of corporate communication/PR through its contribution to enterprise strategy and enterprise governance. Paper presented at 10th EUPRERA Conference, Milan, Italy, October 16-18.

Sun, Jialu, Meifang Yao, Weiyong Zhang, Yong Chen, and Yan Liu. 2016. Entrepreneurial environment, market-oriented strategy, and entrepreneurial performance: A study of Chinese automobile firms. Internet Research 26: 546-62. [CrossRef]

Tata, Jasmine, and Sameer Prasad. 2015. Immigrant family businesses: social capital, network benefits and business performance. International Journal of Entrepreneurial Behavior E Research 21: 842-66.

Teeratansirikool, Luliya, Sununta Siengthai, Yuosre Badir, and Chotchai Charoenngam. 2013. Competitive strategies and firm performance: the mediating role of performance measurement. International Journal of Productivity and Performance Management 62: 168-84. [CrossRef]

Unger, Jens M., Andreas Rauch, Michael Frese, and Nina Rosenbusch. 2011. Human capital and entrepreneurial success: A meta-analytical review. Journal of Business Venturing 26: 341-58. [CrossRef]

Wagner, Christian. 2004. Enterprise strategy management systems: current and next generation. The Journal of Strategic Information Systems 13: 105-28. [CrossRef]

Wang, Linda C., David Ahlstrom, Anil Nair, and Rachel Z. Hang. 2008. Creating globally competitive and innovative products: China's next Olympic challenge. SAM Advanced Management Journal 73: 4-16.

Yang, Songling, Muhammad Ishtiaq, and Muhammad Anwar. 2018. Enterprise Risk Management Practices and Firm Performance, the Mediating Role of Competitive Advantage and the Moderating Role of Financial Literacy. Journal of Risk and Financial Management 11: 1-35.

Zhang, Yan, and Haiyang Li. 2010. Innovation search of new ventures in a technology cluster: The role of ties with service intermediaries. Strategic Management Journal 31: 88-109. [CrossRef]

Zhu, Yadong. 2013. An Analysis of Relations between Industrial Strategy and Enterprise Strategy. In 2013 the International Conference on Education Technology and Information System (ICETIS 2013). Paris: Atlantis Press.

(C) 2019 by the authors. Licensee MDPI, Basel, Switzerland. This article is an open access article distributed under the terms and conditions of the Creative Commons Attribution (CC BY) license (http://creativecommons.org/licenses/by/4.0/). 